\title{
क개오 \\ Pengaruh Pemberian Tablet Fe Terhadap Hemoglobin Pada Taruni Politeknik Ilmu Pelayaran Semarang
}

\author{
Anggi Vina Hariyati ${ }^{1}$, Adil Zulkarnain ${ }^{2}$, Cahyaningrum ${ }^{3}$ \\ ${ }^{1,2,3}$ Program studi D-IV Kebidanan, Fakultas Ilmu Kesehatan \\ Universitas Ngudi Waluyo \\ Email: anggivina8@gmail.com
}

\begin{abstract}
ABSTRAK
Anemia merupakan salah satu masalah kesehatan masyarakat yang perlu khusus nya pada remaja putri yang perlu mendapatkan perhatian khusus karena remaja putri mengalami mestruasi tiap bulan dan dalam masa pertumbuhan . Hasil Data Dinas Kesehatan Kota Semarang tahun 2011. Kejadian anemia pada remaja usia 10-19 sebanyak 68,24\%. Untuk menangani masalah tersebut pencegahan yang dilakukan yaitu dengan cara mengukur hemoglobin dan pemberian suplemen tablet tambah darah. Penelitian ini bertujuan untuk melihat Pengaruh Pemberian Tablet Fe Terhadap Hemoglobin Pada Taruni Politeknik Ilmu Pelayaran Semarang. Penelitian ini bertujuan untuk melihat Pengaruh Pemberian Tablet Fe Terhadap Hemoglobin Pada Taruni Politeknik Ilmu Pelayaran Semarang. Jenis penelitian ini menggunakan pre-eksperimen design dengan rancangan Two group pretest posttest. Populasi dalam penelitian iniadalah seluruh taruni politeknik ilmu pelayaran semarang semester 4 berjumlah 50 taruni dengan jumlah sempel 34 responden dengan tehnik pengambilan sempel purposive sampling. Pengambilan data dengan melakukan pemeriksaan Hemoglobin. Penelitian menunjukan bahwa rata-rata Hemoglobin sebelum diberikan pada taruni kelompok intervensi dan kontrol sama yaitu 11,29 g/dl. Dan setelah diberikan pada kelompok intervensi rata-rata meningkat menjadi 13,69 g/dl, sedangkan kelompok kontrol rata-rata sebesar 11,72 g/dl. Analisis bivariate Menggunakan uji $t$ independen, didapatkan nilai t hitung 6,136 dengan p-value sebesar 0,000. Terlihat bahwa p-value 0,000 $<\alpha(0,05)$, ini menunjukkan bahwa ada perbedaan secara signifikan penurunan (selisih) kadar Hemoglobin b pada taruni sesudah diberikan tablet penambah darah antara kelompok intervensi dan kontrol pada taruni Politeknik Ilmu Pelayaran Semarang. Hendaknya bagi remaja putri lebih banyak mengomsumsi makanan yang mengandung zat besi atau mengomsumsi suplemen yang mengandung besi seperti Fe terutama saat mestruasi.
\end{abstract}

Kata Kunci : Anemia, Hemoglobin, Taruni, Tablet Fe.

\begin{abstract}
The Effect of Fe Tablets on Hemoglobin in Taruni Polytechnic Science of Shipping Semarang

Anemia is one of the public health problems that need more attention of the female because they experience menstruation and they are in the growth phase.

Pengaruh Pemberian Tablet... Anggi Vina Hariyati, Adil Zulkarnain, Cahyaningrum Journal of Holistics and Health Sciences Vol. 2, No. 2 September 2020
\end{abstract}


From the data of Semarang City Health Office in 2011, it is shown the incidence of anemia in adolescents aged 10-19 years old are 68.24\%. The prevention effort of the case is by measuring hemoglobin and prescribing blood supplement. The objective of the study is to find out the effect of Fe tablets on Hemoglobin in Semarang Merchant Marine Polytechnique students. The objective of the study is to find out the effect of Fe tablets on Hemoglobin in Semarang Merchant Marine Polytechnique students. This research used pre-experimental design with the two group pretest posttest. The population in this Study were all Merchant Marine Polytechnique Semarang at the 4th semester of female students amounting to 50 with the total respondents 34 respondents taken with purposive sampling technique. The data were collected by performing Hemoglobin examination. The results of the study show that the average Hemoglobin before being prescribed Fe on the intervention and control group was $11.29 \mathrm{~g} / \mathrm{dl}$. After being prescribed Fe to the intervention group, it is found the average increased to $13.69 \mathrm{~g} / \mathrm{dl}$, while in the control group it is found averaged $11.72 \mathrm{~g} / \mathrm{dl}$. Bivariate Analysis uses an independent $t$ test, the value of $t$ is 6.136 with a p-value of 0.000 . It shows that the p-value is $0,000<((0.05)$, this indicates that there is a significant difference in the decrease in Hemoglobin levels in the population after being prescribed blood supplement between the intervention and control groups in The Semarang Merchant Marine Politechnique Students. It is suggested that the female adolescents to consume more iron-containing foods or consume Fe supplements such as $\mathrm{Fe}$, during menstruation.

Keywords: Anemia, Hemoglobin, Merchant Marine, Fe Tablets.

\section{PENDAHULUAN}

Anemia adalah kondisi dimana kadar hemoglobin kurang dari yang diharapkan sesuai dengan usia dan jenis kelamin, dimana kadar Hemoglobin saat kita lahir tinggi (20 gram/dl), tetapi menurun pada kehidupan tiga bulan pertama sampai angka terendah (10 gram/dl) sebelum meningkat kembali menjadi nilai dewasa normal (>12 gram/dl pada wanita dan $>13$ gram/dl pada pria). Konsentrasi $\mathrm{Hb}$ adalah indikator yang paling dapat diandalkan dari anemia pada tingkat populasi. Anemia banyak terjadi pada semua kelompok usia terutama pada remaja dan ibu hamil. Anemia pada remaja putri sampai saat ini masih cukup tinggi. Data Kemenkes tahun 2013 menunjukkan prevalensi anemia gizi pada kelompok usia remaja ( $\geq 15$ tahun) adalah $22.2 \%$.
Remaja putri (10-19 tahun) merupakan salah satu kelompok yang rawan mengalami anemia. Remaja putri merupakan generasi masa depan bangsa yang nantinya akan menentukan generasi berikutnya. Menurut (WHO, 1968) dalam Adriani \& Wirjatmadi (2012).

Di kota semarang sendiri angka kejadian anemia pada remaja usia 10-19 tahun di tahun 2008 sebanyak $25,55 \%$ remaja yang menderita anemia, meningkat pada tahun 2009 menjadi 40,13\% remaja putri, tahun 2010 menjadi $41,25 \%$ remaja putri yang menderita anemia dan tahun 2011 sebanyak 68,24\% yang menderita anemia (Dinas Kesehatan Kota Semarang, 2011). Berdasarkan hasil survei pelacakan anemia pada remaja usia 10-19 tahun menunjukan bahwa dari 37 Kecamatan di Kota Semarang 
terdapat peningkatan angka kejadian anemia terbesar yaitu di Puskesmas Karangdoro Kota Semarang dengan angka peningkatan kejadian anemia 2,4 kali lebih besar dari tahun sebelumnya (Dinas Kesehatan Kota Semarang, 2011).

Hasil studi pendahuluan yang saya lakukan di Politeknik Ilmu Pelayaran Semarangpada tanggal 08 April sampai dengan 08 Mei 2019, penelitian dilakukan selama 1 bulan, didapatkan hasil pada saat pemeriksaan pre-test pada 50 taruni semester 4 terdapat 34 taruni yang mengalami kadar hemoglobin $<12$ $\mathrm{mg} / \mathrm{dl}$, dan di bagi menjadi 2 grup yaitu intervensi dan kontrol setelah itu diberikan tablet Fe selama 1 bulan pada kelompok intervensi dan hasil sangat meningkat signifikan. Saya tertarik penelitian disana karena sebelumnya di Politeknik Ilmu Pelayaran Semarang belum pernah ada yang melakukan penelitian tentang pemberian tablet $\mathrm{Fe}$ pada taruni.

1. Umur Responden

Tabel 4.1 Deskripsi Berdasarkan Umur Taruni Semester 4 di Politeknik Pelayaran Semarang

\begin{tabular}{|c|c|c|c|c|c|c|}
\hline Variabel & Kelompok & $\mathbf{N}$ & Mean & SD & Min & Max \\
\hline \multirow[t]{2}{*}{ Umur (th) } & Intervensi & 17 & 18,88 & 0,99 & 18 & 22 \\
\hline & Kontrol & 17 & 18,47 & 0,62 & 17 & 19 \\
\hline
\end{tabular}

4.1 dapat diketahui bahwa dari 17 responden taruni kelompok intervensi, ratarata berumur 18,88 tahun dengan standar deviasi 0,99 , umur taruni paling muda 18 tahun dan paling tua 22

\section{B. Analisis Univariat}

1. Kadar $\mathrm{Hb}$ Taruni Sebelum Diberikan Tablet Tambah Darah pada Kelompok Intervensi dan Kontrol

Tabel 4.2 Deskripsi Berdasarkan Kadar Hb Taruni Sebelum Diberikan Tablet Tambah Darah pada Kelompok Intervensi dan Kontrol peneliti tertarik untuk melakukan penelitian tentang Pengaruh Pemberian Tablet Fe Terhadap Hemoglobin Pada Taruni Politeknik Ilmu Pelayaran Semarang.

\section{METODE}

Jenis penelitian ini menggunakan Eksperimen design dengan rancangan Two group pretest posttest. Populasi dalam penelitian iniadalah seluruh taruni politeknik ilmu pelayaran semarang semester 4 berjumlah 50 taruni dengan jumlah sempel 34 responden dengan tehnik pengambilan sempel purposive sampling. Pengambilan data dengan melakukan pemeriksaan Hemoglobin sebelum dan sesudah pada kelompok intervensi dan kelompok kontrol menggunakan alat Easy Touch.penelitian ini menggunakan uji statistik paired sample t- test.

\section{HASIL DAN PEMBAHASAN} Hasil

\section{A. Karakteristik Responden}




\begin{tabular}{|c|c|c|c|c|c|c|}
\hline Variabel & Kelompok & $\mathbf{N}$ & Mean & SD & Min & Max \\
\hline \multirow{2}{*}{$\begin{array}{l}\text { Kadar } \mathrm{Hb} \\
(\mathrm{g} / \mathrm{dl})\end{array}$} & Intervensi & 17 & 11,29 & 0,45 & 10,2 & 11,9 \\
\hline & Kontrol & 17 & 11,32 & 0,50 & 10,2 & 11,9 \\
\hline \multicolumn{3}{|c|}{ Berdasarkan tabel } & \multicolumn{4}{|c|}{ tinggi $11,9 \mathrm{~g} / \mathrm{dl}$. Sedangkan } \\
\hline \multicolumn{2}{|c|}{$\begin{array}{l}4.2 \text { dapat diketahui bahwa } \\
\text { sebelum diberikan table } \\
\text { tambah darah, rata-rata kada }\end{array}$} & & \multicolumn{4}{|c|}{$\begin{array}{l}\text { pada kelompok kontrol, } \\
\text { sebelum diberikan tablet } \\
\text { tambah darah, rata-rata kadar }\end{array}$} \\
\hline \multicolumn{3}{|c|}{$\begin{array}{l}\text { tambah darah, rata-rata kadar } \\
\mathrm{Hb} \text { taruni } \quad \text { kelompok }\end{array}$} & \multirow{2}{*}{\multicolumn{4}{|c|}{$\begin{array}{l}\mathrm{Hb} \text { taruni sebesar } 11,32 \mathrm{~g} / \mathrm{dl} \\
\text { dengan standar deviasi } 0,50\end{array}$}} \\
\hline \multicolumn{3}{|c|}{ intervensi sebesar $11,29 \mathrm{~g} / \mathrm{dl}$} & & & & \\
\hline \multirow{2}{*}{\multicolumn{3}{|c|}{$\begin{array}{l}\text { dengan standar deviasi } 0,45 \\
\text { g/dl Kadar Hb paling rendah }\end{array}$}} & \multicolumn{4}{|c|}{ g/dl. Kadar $\mathrm{Hb}$ paling rendah } \\
\hline \multirow{2}{*}{\multicolumn{3}{|c|}{ sebesar $10,2 \mathrm{~g} / \mathrm{dl}$ dan paling }} & \multicolumn{4}{|c|}{ sebesar $10,2 \mathrm{~g} / \mathrm{dl}$ dan paling } \\
\hline & & & \multicolumn{4}{|c|}{ tinggi $11,9 \mathrm{~g} / \mathrm{dl}$} \\
\hline
\end{tabular}

2. Kadar $\mathrm{Hb}$ Taruni Sesudah Diberikan Tablet Tambah Darah pada Kelompok Intervensi dan Kontrol

Tabel 4.3 Deskripsi Berdasarkan Kadar Hb Taruni Sesudah Diberikan Tablet Tambah Darah pada Kelompok Intervensi dan Kontrol

\begin{tabular}{lllcccc}
\hline \multicolumn{1}{c}{ Variabel } & Kelompok & N & Mean & SD & Min & Max \\
\hline Kadar $\mathrm{Hb}$ & Intervensi & 17 & 13,69 & 1,04 & 12,4 & 16,0 \\
$(\mathrm{~g} / \mathrm{dl})$ & Kontrol & 17 & 11,72 & 0,36 & 11,0 & 12,3 \\
\hline \multicolumn{3}{c}{ Berdasarkan tabel } & \multicolumn{3}{c}{ sebesar $11,0 \mathrm{~g} / \mathrm{dl}$ dan } & paling \\
4.3 dapat diketahui bahwa & \multicolumn{4}{c}{ tinggi $12,3 \mathrm{~g} / \mathrm{dl}}$.
\end{tabular}
sesudah diberikan tablet tambah darah, rata-rata kadar $\mathrm{Hb}$ taruni kelompok intervensi sebesar 13,69 g/dl dengan standar deviasi 1,04 $\mathrm{g} / \mathrm{dl}$. Kadar $\mathrm{Hb}$ paling rendah sebesar $12,4 \mathrm{~g} / \mathrm{dl}$ dan paling tinggi 16,0 g/dl. Sedangkan pada kelompok kontrol yang tidak diberikan tablet tambah darah, rata-rata kadar $\mathrm{Hb}$ taruni sebesar 11,72 g/dl dengan standar deviasi 0,36 g/dl. Kadar $\mathrm{Hb}$ paling rendah

\section{Analisis Bivariat}

Bagian ini menyajikan analisis bivariat tentang pengaruh pemberian tablet tambah darah terhadap peningkatan kadar Hemoglobin pada Taruni Politeknik Pelayaran Semarang. Untuk mengetahui pengaruh ini digunakan uji t independen dan uji t dependen karena data yang diperoleh berdistribusi normal. Data berdistribusi normal dibuktikan dengan hasil berikut ini.

1. Uji Normalitas

Tabel 4.4 Uji Normalitas

\begin{tabular}{|c|c|c|c|c|c|}
\hline Variabel & Perlakuan & Kelompok & $\mathbf{n}$ & p-value & Kesimpulan \\
\hline \multirow[t]{4}{*}{$\mathrm{Hb}$} & \multirow[t]{2}{*}{ Pretest } & Intervensi & 17 & 0,194 & Normal \\
\hline & & Kontrol & 17 & 0,059 & Normal \\
\hline & \multirow[t]{2}{*}{ Posttest } & Inte & 17 & 0,197 & Normal \\
\hline & & & 17 & 0,198 & Normal \\
\hline \multicolumn{3}{|c|}{ Berdasarkan uji } & \multicolumn{3}{|c|}{ kadar $\mathrm{Hb}$ pretest kelompok } \\
\hline normalitas menggunakan & \multicolumn{2}{|c|}{ menggunakan } & \multicolumn{3}{|c|}{ intervensi dan kontrol } \\
\hline \multirow{2}{*}{\multicolumn{3}{|c|}{$\begin{array}{l}\text { Saphiro Wilk sebagaimana } \\
\text { disaijkan pada tabel } 4.4\end{array}$}} & \multicolumn{3}{|c|}{ masing-masing sebesar 0,194} \\
\hline & & & \multicolumn{3}{|c|}{ dan 0,059 , dan untuk kadar } \\
\hline \multicolumn{3}{|c|}{ didapatkan p-value untuk } & \multicolumn{3}{|c|}{$\mathrm{Hb}$ posttest kelompok } \\
\hline
\end{tabular}


intervensi dan kelompok kontrol masing-masing sebesar 0,197 dan 0,198 yang mana keempat $p$-value tersebut lebih besar dari $\alpha$ $(0,05)$, dan menunjukkan data berdistribusi normal. Karena data yang diperoleh berdisribusi normal maka pengujian dilakukan menggunakan uji $\mathrm{t}$ independen dan uji $t$ dependen.

Tabel 4.5 Uji Homogenitas Kadar Hb Responden Sebelum Perlakuan antara Kelompok Intervensi dan Kelompok Kontrol

\begin{tabular}{clccccc}
\hline \multicolumn{1}{c}{ Variabel } & Kelompok & N & Mean & SD & T & p-value \\
\hline Kadar Hb & Intervensi & 17 & 11,29 & 0,45 & $-0,180$ & 0,858 \\
& Kontrol & 17 & 11,32 & 0,50 & & \\
\hline
\end{tabular}

Berdasarkan tabel 4.5, dapat diketahui bahwa sebelum perlakuan, rata-rata kadar $\mathrm{Hb}$ responden pada kelompok intervensi sebesar $11,28 \mathrm{~g} / \mathrm{dl}$ sedangkan pada kelompok kontrol tidak jauh berbeda yaitu sebesar 11,32 $\mathrm{g} / \mathrm{dl}$.

Berdasarkan uji $\mathrm{t}$ independen, didapatkan nilai $\mathrm{t}$ hitung sebesar $-0,180$ dengan p-value 0,858 . Karena pvalue $0,858>\alpha(0,05)$, maka dapat disimpulkan bahwa 4.

tidak ada perbedaan yang
2. Uji Homogenitas Kadar $\mathrm{Hb}$ Responden Sebelum Perlakuan antara Kelompok Intervensi dan Kelompok Kontrol

Hasil uji ini dikatakan setara atau homogen apabila tidak ada perbedaan secara bermakna antara kadar $\mathrm{Hb}$ responden sebelum perlakuan antara kelompok intervensi dan kelompok kontrol $(\mathrm{p}>0,05)$, begitu juga sebaliknya.

Tabel 4.6 Perbedaan Kadar Hb Taruni Sebelum dan Sesudah Diberikan Tablet Penambah Darah pada Kelompok Intervensi

\begin{tabular}{lllcccc}
\hline Variabel & Perlakuan & $\mathbf{n}$ & Mean & SD & T & p-value \\
\hline Kadar $\mathrm{Hb}$ & Sebelum & 17 & 11,29 & 0,45 & $-8,348$ & 0,000 \\
& Sesudah & 17 & 13,69 & 1,04 & & \\
\hline
\end{tabular}

Berdasarkan tabel

4.6, dapat diketahui bahwa signifikan kadar $\mathrm{Hb}$ responden sebelum perlakuan antara kelompok intervensi dan kelompok kontrol. Ini juga menunjukkan bahwa kedua kelompok memiliki kadar $\mathrm{Hb}$ yang setara sebelum perlakuan atau dapat dinyatakan homogen sebelum penelitian.

3. Perbedaan Kadar $\mathrm{Hb}$ Taruni Sebelum dan Sesudah Diberikan Tablet Penambah Darah pada Kelompok Intervensi 
penambah darah, rata-rata kadar Hb taruni sebesar11,29 g/dl. Kemudian sesudah diberikan tablet penambah darah, rata-rata kadar $\mathrm{Hb}$ taruni meningkat menjadi $13,69 \mathrm{~g} / \mathrm{dl}$ atau rata-rata meningkat $2,4 \mathrm{~g} / \mathrm{dl}$.

Berdasarkan uji $\mathrm{t}$ dependen, didapatkan nilai $\mathrm{t}$ hitung sebesar -8,348 dengan p-value sebesar 0,000 . Terlihat bahwa $\mathrm{p}$-value 0,000

Tabel 4.7 Perbedaan Kadar Hb Taruni Sebelum dan Sesudah Penelitian pada Kelompok Intervensi

\begin{tabular}{clccccc}
\hline \multicolumn{1}{c}{ Variabel } & Perlakuan & $\mathbf{n}$ & Mean & SD & T & p-value \\
\hline Kadar $\mathrm{Hb}$ & Sebelum & 17 & 11,32 & 0,50 & $-2,532$ & 0,022 \\
& Sesudah & 17 & 11,72 & 0,36 & & \\
\hline
\end{tabular}

Berdasarkan tabel

4.7, dapat diketahui bahwa pada kelompok kontrol yang tidak diberikan tablet penambah darah, sebelum penelitian, rata-rata kadar $\mathrm{Hb}$ taruni sebesar 11,32 $\mathrm{g} / \mathrm{dl}$. Kemudian sesudah penelitian, rata-rata kadar $\mathrm{Hb}$ taruni meningkat menjadi $11,72 \mathrm{~g} / \mathrm{dl}$ atau rata-rata meningkat 0,39 $\mathrm{g} / \mathrm{dl}$.

Berdasarkan uji $\mathrm{t}$ dependen, didapatkan nilai $\mathrm{t}$ hitung sebesar -2,532 dengan p-value sebesar 0,022 . Terlihat bahwa p-value 0,022 $<\alpha(0,05)$, ini menunjukkan bahwa ada perbedaan secara signifikan kadar $\mathrm{Hb}$ taruni sebelum dan sesudah penelitian pada kelompok kontrol di Politeknik Pelayaran Semarang. Ini

$\begin{aligned} \text { Tabel 4.8 } & \begin{array}{l}\text { Pengaruh Pemberian Tablet Tambah Darah terhadap } \\ \text { Peningkatan Kadar Hemoglobin pada Taruni Politeknik }\end{array}\end{aligned}$

Tabel 4.8 Pengaruh Pemberian Tablet Tambah Darah terhadap
Peningkatan Kadar Hemoglobin pada Taruni Politeknik Pelayaran Semarang

\begin{tabular}{lllllll}
\hline Variabel & Kelompok & $n$ & Mean & SD & T & p-value
\end{tabular}

menunjukkan bahwa pada kelompok kontrol yang tidak diberikan tabel penambah darah, kadar $\mathrm{Hb}$ responden juga mengalami peningkatan secara signifikan.

6. Pengaruh pemberian tablet tambah darah terhadap peningkatan kadar Hemoglobin pada Taruni Untuk menguji pengaruh ini, dilakukan uji perbedaan selisih kadar $\mathrm{Hb}$ taruni sesudah perlakuan antara kelompok intervensi dan kelompok kontrol, jika terdapat perbedaan signifikan $(\mathrm{p}<\alpha \quad(0,05))$ maka disimpulkan ada pengaruh pemberian tablet tambah darah terhadap peningkatan kadar Hemoglobin, begitupun sebaliknya. $<\alpha(0,05)$, ini menunjukkan bahwa ada perbedaan secara signifikan kadar $\mathrm{Hb}$ taruni sebelum dan sesudah diberikan tablet penambah darah di Politeknik Pelayaran Semarang.

5. Perbedaan Kadar $\mathrm{Hb}$ Taruni Sebelum dan Sesudah Penelitian pada Kelompok Kontrol 


\begin{tabular}{lllllll}
\hline Selisih Hb & Intervensi & 19 & 2,40 & 1,19 & 6,136 & 0,000 \\
& Kontrol & 19 & 0,39 & 0,64 & & \\
\hline
\end{tabular}

Berdasarkan tabel 4.8, dapat diketahui bahwa pada kelompok intervensi sesudah diberikan tablet penambah darah, rata-rata peningkatan kadar $\mathrm{Hb}$ pada taruni sebesar 2,40 g/dl. Sedangkan pada kelompok kontrol yang tidak diberikan tablet penambah darah hanya meningkat sebesar $0,39 \mathrm{~g} / \mathrm{dl}$.

Berdasarkan uji $t$ independen, didapatkan nilai $\mathrm{t}$ hitung 6,136 dengan $\mathrm{p}$ value sebesar 0,000 . Terlihat bahwa p-value $0,000<\alpha$ $(0,05)$, ini menunjukkan bahwa ada perbedaan secara signifikan penurunan (selisih) kadar $\mathrm{Hb}$ pada taruni sesudah diberikan tablet penambah darah antara kelompok intervensi dan kontrol. Ini juga menunjukkan bahwa ada pengaruh secara signifikan tablet penambah darah terhadap peningkatan kadar Hb pada Taruni di Politeknik Pelayaran Semarang.

\section{Pembahasan}

\section{A. Analisis Univariat}

1. Gambaran Kadar $\mathrm{Hb}$ Teruni Sebelum diberikan Tablet Tambah Darah pada kelompok kontrol dan intervensi.

Berdasarkan hasil penelitian dapat diketahui bahwa sebelum diberikan tablet tambah darah, rata-rata kadar $\mathrm{Hb}$ taruni kelompok intervensi sebesar 11,29 g/dl, kadar $\mathrm{Hb}$ paling rendah sebesar 10,2 g/dl dan paling tinggi 11,9 g/dl. Sedangkan pada kelompok kontrol, sebelum diberikan tablet tambah darah, rata-rata kadar $\mathrm{Hb}$ taruni sebesar 11,32 g/dl. kadar $\mathrm{Hb}$ paling rendah sebesar 10,2 $\mathrm{g} / \mathrm{dl}$ dan paling tinggi $11,9 \mathrm{~g} / \mathrm{dl}$.

Anemia kurangnya zat besi adalah masalah yang paling umum dijumpai terutama pada wanita. Zat besi diperlukan untuk membentuk sel-sel darah merah, dikonveksi menjadi haemoglobin. Beredar ke seluruh jaringan tubuh, berfungsi sebagai pembawa oksigen. Remaja wanita membutuhkan lebih banyak zat besi dari pada pria. Agar zat besi yang diabsorpsi lebih banyak tersedia oleh tubuh, maka diperlukan bahan makanan yang berkualitas tinggi. Seperti pada daging, ikan, hati, ayam dna selain itu bahan makanan yang mengandung vitamin c membantu penyerapan zat besi (Irianto Koes. 2015). Kekurangan zat besi terjadi dalam tiga tahap yaitu tahap pertama terjadi bila simpanan besi berkurang yang terlihat pada penurunan feritin dalam plasma hingga $12 \mathrm{ug} / \mathrm{L}$. Hal ini dikompensasi dengan peningkatan absorpsi besi yang terlihat dari peningkatan kemampuan mengikat besi total (Total Iron Binding Capacity). Pada tahap ini belum terlihat 
perubahan fungsional tubuh. Tahap kedua terlihat dengan habisnya simpanan besi, menurunnya transferin hingga kurang dari $16 \%$ dan meningkatnya protoporfirin yaitu bentuk pendahulu darah. Pada tahap ini nilai hemoglobin di dalam darah masih berada pada $95 \%$ nilai normal. Hal ini dapat mengganggu metabolisme energi, sehingga menyebabkan menurunnya kemampuan bekerja. Pada tahap ketiga terjadi anemia gizi besi, dimana kadar hemoglobin total turun di bawah nilai normal (Almatsier, 2010).

$$
\text { Gejala anemia }
$$

defisiensi besi dibagi menjadi dua, yaitu tanda dan gejala anemia defisiensi besi tidak khas serta tanda dan gejala anemia defisiensi besi yang khas. Tanda dan gejala anemia defisiensi besi tidak khas hampir sama dengan anemia pada umumnya yaitu: cepat lelah atau kelelahan, hal ini terjadi karena simpanan oksigen dalam jaringan otot kurang sehingga metabolisme otot terganggu; nyeri kepala dan pusing merupakan kompensasi dimana otak kekurangan oksigen, karena daya angkut hemoglobin berkurang; kesulitan bernapas, terkadang sesak napas merupakan gejala, dimana tubuh memerlukan lebih banyak lagi oksigen dengan cara kompensasi pernapasan lebih dipercepat; palpitasi, dimana jantung berdenyut lebih cepat diikuti dengan peningkatan denyut nadi; dan pucat pada muka, telapak tangan, kuku, membran mukosa mulut dan konjungtiva.

Gejala anemia zat besi biasanya tidak khas dan sering tidak jelas, seperti pucat, mudah lelah, berdebar, takikardia dan sesak nafas. Kepucatan bisa diperiksa pada telapak tangan, kuku dan konjungtiva palpebral, kepucatan pada kuku dan telapak tangan lebih sensitif dan spesifik jika dibandingkan dengan konjungtiva palpebra untuk mendeteksi gejala anemia. Kekurangan besi pada umumnya menyebabkan pucat, rasa lemah, letih, pusing, kurang nafsu makan, menurunnya kebugaran tubuh, menurunnya kemampuan bekerja, menurunnya kekebalan tubuh dan gangguan penyembuhan luka. Di samping itu kemampuan mengatur suhu tubuh juga menurun ( Arisman, 2010).

Menurut Hedi R. Dewoto dan S. Wardhini B.P (2013) Jumlah fe yang dibutuhkan setiap hari dipengaruhi oleh berbagai faktor. Faktor umur, jenis kelamin, jumlah darah dalam tubuh dapat mempengaruhi kebutuhan, walaupun keadaan depot Fe memegang peranan yang penting pula. Dalam keadaan normal dapat diperkirakan bahwa seorang laki-laki dewasa memerlukan asupan sebesar $10 \mathrm{mg}$, dan wanita memerlukan $12 \mathrm{mg}$ 
sehari guna memenuhi ambilan sebesar masingmasing $1 \mathrm{mg}$ dan $1,2 \mathrm{mg}$ sehari. Bila kebutuhan ini tidak dipenuhi, $\mathrm{Fe}$ yang terdapat dalam gudang akan digunakan dan gudang lambat laun menjadi kosong. Akibatnya timbul anemia defisiensi Fe. Biasanya disebabkan karena absorpsi yang jelek, perdarahan krinik dan kebutuhan yang meningkat. Keadaan ini memrlukan penambah $\mathrm{Fe}$ dalam bentuk obat.

Menurut Briawan (2014) Kebutuhan zat besi terabsorbsi pada remaja wanita diperkirakan sekitar 1,9 mg/hari, berdasarkan ratarata kebutuhan untuk tumbuh (0,5 mg), basar (0,75 mg), dan kehilangan darah menstruasi 90,6 mg). apanila AKG zat besi $15 \mathrm{mg} /$ hari, dengan asumsi penyerapan zat besi 10-15\%, akan menghasilkan asupan zat besi sekitar 1,5-2,2 $\mathrm{mg} /$ hari. Jumlah ini cukup untuk mempertahankan

keseimbangan zat besi didalam tubuh, termasuk untuk penyimpanan sebesar $300 \mathrm{mg}$.

2. Gambaran kadar hemoglobin taruni sesudah diberikan tablet tambah darah pada taruni politeknik ilmu pelayaran semarang.

Berdasarkan hasil penelitian diketahui bahwa sesudah diberikan tablet tambah darah rata-rata kadar hemoglobin taruni pada kelompok intervensi sebesar $13,69 \mathrm{~g} / \mathrm{dl}$, paling rendah sebesar 12,4 g/dl, paling tinggi $16,0 \mathrm{~g} / \mathrm{dl}$. Sedangkan pada kelompok kontrol yang tidak diberikan tablet tambah darah rata-rata sebesar 11,72 $\mathrm{g} / \mathrm{dl}$, paling rendah $11,0 \mathrm{~g} / \mathrm{dl}$ dan paling tinggi $12,3 \mathrm{~g} / \mathrm{dl}$. Dalam penelitian ini dosis zat besi yang diberikan pada taruni politeknik ilmu pelayaran semarang yaitu fero sulfat $200 \mathrm{mg}$ atau setara $60 \mathrm{mg}$ besi elemental dan $0,25 \mathrm{mg}$ asam folat, tablet tambah darah dengan cara dikomsumsi selama satu bulan pada taruni yang mengalami kadar hemoglobin $<12 \mathrm{mg} / \mathrm{dl}$ dan < $12 \mathrm{mg} / \mathrm{dl}$. Dari hasil penelitian tersebut menunjukan ada perubahan kadar hemoglobin siswi sesudah diberikan tablet tambah darah $(\mathrm{Fe})$ sudah tidak ada lagi yang mengalami kadar hemoglobin rendah. Dan untuk peningkatan kadar hemoglobin taruni yang mengalami kenaikan sangat signifikan faktornya bisa dikarenakan pola nutrisi yang dimakan diluar makanan yang diberikan dari asrama, bisa karena pola mestruasi dari setiap taruni berbedabeda sehingga menyebabkan beberapa taruni mengalami kenaikan kadar Hemoglobin signifikan. Ini sudah membuktikan bahwa pemberian tablet $\mathrm{Fe}$ ini efektik untuk meningkatkan kadar hemoglobin pada remaja

Zat besi merupakan suplemen penambah darah yang dibutuhkan untuk 
mencegah terjadinya anemia. Zat besi adalah mineral mikro yang paling banyak terdapat didalam tubuh manusia dan hewan yaitu sebanyak 3-5 gram didalam tubuh manusia dewasa. Zat besi mempunyai fungsi sabagai alat angkut oksigen dari paru-paru kejaringan tubuh ( Depkes kesehatan RI, 2014).

Penelitian yang

dilakukan Noky Tri

Rachmadianto tahun (2014). Efektifitas Pemberian Tablet Tambah Darah Terhadap Kadar Hb Siswi SLTPN 1 Donorojo Kecamatan Donorojo Kabupaten Pacitan. Didapatkan 158 responden mengalami anemia. Hal ini ternyata berpengaruh menurunkan kemampuan dan konsentrasi belajar, menghambat pertumbuhan fisik dan kecerdasan otak, meningkatkan resiko menderita infeksi, menurunkan daya tahan tubuh sehingga mudah sakit menurunkan semangat, konsentrasi dan prestasi belajar, tujuan penelitian untuk mengetahui efektivitas pemberian tablet tambah darah terhadap kadar $\mathrm{Hb}$. Penelitian ini merupakan penelitian kuantitatif eksperimental. Sampel diambil dengan proportionate random sampling sebanyak 158 responden. Alat pengumpulan data dalam penelitian ini berupa pengecekan kadar $\mathrm{Hb}$ sebelum dan sesudah pemberian tablet tambah selama 1 bulan pemberian
Fero Sulfat $200 \mathrm{mg}$ atau setara $60 \mathrm{mg}$ besi elemental dan 0,25 asam folat, Dari hasil penelitian ini menunjukan ada perubahan kadar hemoglobin siswi sebelum dan sesudah pemberian Tablet Tambah Darah tidak ada yang mengalami kadar $\mathrm{Hb}$ ringan sehingga ada evektifitas pemberian tablet tambah darah terhadap kadar $\mathrm{Hb}$ siswi. . Analisis data penelitian ini menggunakan uji paired $\mathrm{t}$ test. Mayoritas siswi sebelum diberi tablet tambah darah mengalami anemia ringan sebanyak 102 siswi $(64,56 \%)$ dan setelah diberi tablet tambah darah mengalami anemia ringan 70 siswi $(44,30 \%)$. Hasil uji diketahui pemberian tablet tambah darah efektif terhadap kadar $\mathrm{Hb}$ siswi, yang ditunjukkan nilai $\mathrm{p}=0,026$ $(\mathrm{p}<0,05)$, dan pemberian tablet tambah darah sangat efektif terhadap peningkatan kadar $\mathrm{Hb}$ siswi SLTP N I Donorojo Kecamatan Donorojo Kabupaten Pacitan.

Menurut penelitian yang telah dilakukan Novia Arini, Terbuat Bakta, Desak Made Citrawati tahun (2017) dengan judul Dampak Suplemen Besi Terhadap Kadar Hemoglobin Pada Gadis Remaja Di Kabupateng Bangle, Bali, Indonesia. Prevalensi rata-rata anemia pada remaja putri di Kabupaten Bangli adalah $36,8 \%$. Jumlah tertinggi kejadian anemia pada remaja putri di SMP 4 hasil: 
Prevalensi rata-rata anemia pada remaja putri di Kabupaten Bangli adalah $36,8 \%$. Jumlah tertinggi kejadian anemia pada remaja putri di SMP 4 Tembuku oleh $66,7 \%$ dan insiden terendah anemia di SMP 3 Susut $22,4 \%$. Bahwa suplementasi zat besi pada anak perempuan remaja menderita anemia memiliki dampak yang signifikan terhadap pengurangan kejadian anemia pada anak perempuan remaja. Rata-rata penurunan kejadian anemia pada remaja putri adalah $24,9 \%$.

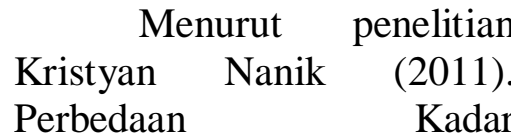

Hemoglobin Sebelum Dan Setelah Pemberian Tablet Besi ( Fe ) Pada Santri Putri Di Pondok Pesantren AlHidayah Kabupaten Grobogan. Pada Populasi penelitian berjumlah 46 orang. Sampel berjumlah 12 orang untuk masing-masing kelompok eksperimen dan kontrol. Instrumen yang digunakan

sianmethemoglobin. Data dianalisis menggunakan uji $\mathrm{t}$ tidak

berpasanganBerdasarkan analisis uji t-test berpasangan pada kelompok eksperimen menunjukkan bahwa nilai $p$ value adalah 0,0001 hal ini berarti $\mathrm{p}<0,05$, maka terdapat perbedaan kadar hemoglobin yang signifikan antara kadar hemoglobin pretest dan kadar hemoglobin post-test dengan mengkonsumsi tablet besi $(\mathrm{Fe})$.

Menurut penelitian yang telah dilakukanSaridewi Wisdyana (2017). Dengan judul Analisis Rata-rata Perbedaan Peningkatan Hemoglobin Remaja Putri yang Mengonsumsi Tablet BesiHasil pengamatan lebih lanjut menemukan bahwa 35 responden (100\%) mengonsumsi tablet $\mathrm{Fe}$ pada malam hari ini terjadi penin gkatan yang signifikan. Ini terjadi karena responden merasa nyaman dan tidak mengalami perasaan mual yang mungkin disebabkan oleh tablet Fe. Selain itu, ada juga responden yang merasa nyaman mengonsumsi tablet di malam hari karena mereka melakukannya bersama dengan persiapan mereka untuk sekolah pada hari berikutnya. Ada enam responden yang mengonsumsi tablet Fe dalam interval waktu $<24$ jam. Di antara enam responden tersebut, lima responden $(83,3 \%) \quad$ mengalami peningkatan kadar hemoglobin, sedangkan satu responden $(16,7 \%)$ tidak mengalami peningkatan kadar hemoglobin. Di sisi lain, dari 29 responden yang mengonsumsi tablet dalam interval waktu $\geq 24$ jam, ada 28 responden $(96,6 \%)$ yang kadar hemoglobinnya meningkat. Sementara itu, hanya ada satu responden yang kadar hemoglobinnya tidak meningkat. Hal ini terjadi karena responden 
mengkonsumsi zat lain yang menghambat penyerapan $\mathrm{Fe}$, sehingga zat besi tidak dapat diserap sepenuhnya oleh tubuh.

Menurut penelitian Permatasari Tyas, Dkk (2018). Program suplementasi besi untuk remaja putri bertujuan menurunkan prevalensi anemia, tetapi hasilnya tidak selalu sukses. Penelitian ini bertujuan untuk melihat efektivitas program suplementasi besi pada remaja putri di Kota Bogor. Desain yang digunakan yakni quasi experiment pre-post intervensi pada study effectiveness. Penelitian berlangsung dari September 2016 sampai Januari 2017 bersama Dinas Kesehatan Kota Bogor. Jumlah subyek penelitian yakni 172 remaja putri usia (10-18 tahun). Hasil penelitian menunjukkan prevalensi anemia $(\mathrm{Hb}$ $<12 \mathrm{~g} / \mathrm{dl}$ ) sebelum program $20.7 \%$ dan menurun menjadi $15.2 \%$ setelah 4 bulan intervensi. Hasil analisis regresi logistik menunjukkan bahwa faktor yang mempengaruhi peningkatan kadar $\mathrm{Hb}$, yakni status $\mathrm{Hb}$ awal

$(\mathrm{p}<0.05 ; \mathrm{OR}=3.52 ; \mathrm{CI} 95 \%=1.4$ 0-8.85). Program suplementasi besi pada remaja putri di Kota Bogor belum berjalan secara efektif.

Menurut penelitian Susanti Yeti (2016). Berjudul Suplementasi Besi Mingguan Meningkatkan Hemoglobin Sama Efektif Dengan
Kombinasi Mingguan Dan Harian Pada Remaja Putri. Penelitian eksperimental ini bertujuan untuk mengkaji perbedaan efektivitas tiga cara pemberian suplementasi besi terhadap perubahan kadar hemoglobin pada remaja putri. Tiga kelompok intervensi menerima suplemen besi $(60 \mathrm{mg}$ besi elemental dan $0,25 \mathrm{mg}$ asam folat) selama 14 minggu di Kabupaten Tasikmalaya pada bulan Maret-Juni 2015. Kelompok tersebut masingmasing menerima suplemen besi secara mingguan (M), mingguan dan setiap hari selama 10 hari menstruasi (M+Mens), serta mingguan disertai pendidikan gizi (M+PG). Hasil penelitian menunjukkan bahwa peningkatan kadar hemoglobin tidak berbeda nyata $(p>0,05)$ pada semua kelompok perlakuan $(\mathrm{M}+\mathrm{PG}$ 0,63 $\pm 1,16 \quad \mathrm{~g} / \mathrm{dl}, \quad \mathrm{M}+\mathrm{Mens}$ $0,48 \pm 1,04 \mathrm{~g} / \mathrm{dl}$, dan $\mathrm{M}$ $0,44 \pm 1,13 \quad \mathrm{~g} / \mathrm{dl}$ ). Suplementasi besi dapat menurunkan prevalensi anemia masingmasing sebesar $15,8 \%$ (M), $18,0 \%$ (M+Mens) dan 4,9\% (M+PG). Suplementasi besi secara mingguan memiliki efektivitas yang sama dengan mingguan dan selama menstruasi dalam meningkatkan kadar hemoglobin pada remaja putri. Suplementasi besi pada remaja sebaiknya diberikan secara intermittent (mingguan) dengan manfaat tambahan yaitu tingginya 
kepatuhan konsumsi suplemen.

\section{B. Analisis Bivariat}

1. Pengaruh efektivitas pemberian tablet tambah darah terhadap peningkatan kadar hemoglobin kelompok intervensi pada taruni politeknik ilmu pelayaran semarang.

Berdasarkan hasil penelitian bahwa kelompok intervensi sesudah diberikan tablet penambah darah, ratarata peningkatan kadar $\mathrm{Hb}$ pada taruni sebesar 2,40 g/dl. Sedangkan pada kelompok kontrol yang tidak diberikan tablet penambah darah hanya meningkat sebesar 0,39 g/dl. Berdasarkan uji $\mathrm{t}$ independen, didapatkan nilai $\mathrm{t}$ hitung 6,136 dengan $\mathrm{p}$ value sebesar 0,000 . Terlihat bahwa p-value $0,000<a$ $(0,05)$, ini menunjukan bahwa ada perbedaan secara signifikan penurunan (selisih) kadar hb pada taruni sesudah diberikan tablet penambah darah antara kelompok intervensi dan kontrol. Ini juga menunjukan ada pengaruh secara signifikan tablet penambah darah terhadap peningkatan kadar hemoglobin kadar hb pada taruni politeknik ilmu pelayaran semarang. Tablet $\mathrm{Fe}$ ini sendiri efektif untuk meningktakan kadar hemoglobin pada remaja khusus nya remaja putri untuk persiapan sebelum hamil karena jika tidak di tangani akan berpontensi melahirkan bayi dengan tubuh pendek, dan juga BBLR.

Menururt Menururt

Sani R (2014) dalam Cahyaningtyas kartika dwi (2017). Mengkonsumsi tablet $\mathrm{Fe}$ dapat dibarengi dengan makanan atau minuman yang mengandung vitamin $\mathrm{C}$ atau jus jeruk yang lebih cepat menyerap zat besi atau bersaman dengan makan daging, ikan, ayam sehingga dapat menstimulasi asam lambung. Saat mengkonsumsi tablet tambah darah tidak diperbolehkan makan atau minum yang mengandung alkohol, teh. Kopi atau buahbuahan yang mengandung alkohol seperti durian, tape, nanas, mangga dikarenakan dapat menurunkan penyerapan zat besi dalam tubuh sehingga manfaatnya menjadi berkurang. Untuk mengurangi gejala mual dan muntah waktu yang tepat minum tablet $\mathrm{Fe}$ setelah makan malam atai menjelang tidur.Menurut Sani R (2014) Dalam cahyaningtyas kartika dwi (2017). Mengomsumsi tablet fe dapat mengobati wanita dan remaja putri yang mengalami anemia, meningkatkan kemampuan belajar, meningkatkan status gizi dan kesehata remaja.

Menurut Sunita

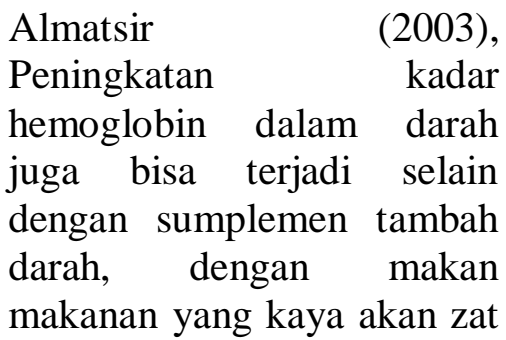


besi, asam folat juga vitamin B dan mengomsumsi jenis makanan yang mudah menyerap zat besi, missal makanan yang mengandung vitamin $\mathrm{C}$ tinggi dan menghindari makanan atau minuman yang menghambat penyerapan zat besi, misal kopi dan teh.

Menurut Noky Tri Rachmadianto (2014). Juga menyatakan evektifitas pemberian tablet tambah darah yang diberikan setiap hari selama 1 bulan juga evektif dalam meningkatkan kadar hemoglobin. Berdasarkan penelitian Cahyaningtyas kartika dwi (2017). Menunjukan pengaruh konsumsi tablet Fe terhadap peningkatan kadar hemoglobin pada remaja putri di SMAN 2 Ngaglik Kabupaten Sleman selama 1 bulan ada pengaruh konsumsi tablet Fe terhadap peningkatan kadar hemoglobin pada remaja putri di SMAN 2 Nggalik.Menurut penelitian Giyanti Fitri (2016). Tentang pengaruh pemberian tablet Fe terhadap kenaikan kadar Hemoglobin remaja putri dengan anemia di SMK Negri 1 Ponjong Gunung Kidul, yang diberikan tablet Fe sehari satu kali menunjukan ada pengaruh kenaikan kadar hemoglobin.

\section{SIMPULAN}

Sebaikanya pemberian tablet tambah darah pada remaja lebih ditingkatkan dan diawasi langsung oleh petugas kesehatan agar tidak terjadi lagi remaja yang mengalami anemia atau kadar hemoglobin $<12$ $\mathrm{mg} / \mathrm{dl}$, karena remaja pertumbuhannya sangat cepat, kehilangan darah rutin dalam setiap bulanya, calon ibu yang akan membutuhkan banyak darah pada saat persalinan. Jika seorang remaja putri menderita anemia dan kemudian hamil maka akan berpotensi melahirkan bayi dengan tubuh pendek, dan juga BBLR.

\section{DAFTAR PUSTAKA}

Anief. 2018. Prinsip umum dan dasar farmokologi. Yogyakarta: UGM. Hal 4.

Almatsir Sunita. 2013. Prinsip Dasar Ilmu Gizi. Jakarta : PT. Gramedia Pusaka Utama.

Arisman. 2010. Gizi Dalam Daur Kehidupan. Jakarta:Penerbit Buku Kedokteran : EGC.

Arikunto, S. 2010. Prosedur Penelitian Suatu Pendekatan Praktik. Jakarta: Rineka Cipta.

Arini. Dkk. 2017. The impact of iron supplementation toward hemoglobin levels on teenage girls in bangle regency. International Journal of Research In Medical Sciences, 2017, Vol 5, Issue 8.

Andriani Wirjatmadi, Dkk. 2012. Pengaruh Suplemen Besi Dan Zink Terhadap Kadar $\mathrm{Hb}$ Dan Kesegaran Jasmani Remaja Putri Yang Anemia Defisiensi Besi. The Indonesia Journal Of Public Health, 2012, Vol 9. 
Bobak. 2014. Buku ajar keperawatan maternitas. Ed. 4. Jakarta: penerbit buku kedokteran EGC.

Briawan. 2014. Anemia masalah gizi pada remaja remaja wanita. Jakarta: EGC.

Dharma, Kusuma Kelana. 2011, Metodologi Penelitian Keperawatan: Panduan Melaksanakan Dan Menerapkan Hasil Penelitian, Jakarta: Trans Info Media.

Dinas kesehatan Kota Semarang. 2016. 200 pelajar SMP-SMA Ikuti launching Gerakan Minum Tablet Fe. Semarang: Profil Kesehatan

Depatemen Kesehatan RI Tahun 2014, Pusat Dana Informasi. Profil Kesehatan Kabupaten Semarang 2014. Semarang.

Dinkes Provinsi Jateng. 2011. Profil Kesehatan provinsi jateng 2011. Semarang.

Fadil Oenzil. 2012. Gizi Meningkatakan Kualitas Manula. Jakarta: EGC.

Fatmah. 2010. Gizi Usia Remaja. Erlangga : Jakarta

Irianto Koes. 2014. Gizi Seimbang Dalam Kesehatan Reproduksi. Bandung: ALFABETA, CV

Kemenkes RI. Hasil Riset Kesehatan Dasar 2013. Jakarta : Badan Penelitian dan Pengembangan Kesehatan; 2013.
Kementerian Kesehatan Republik Indonesia. 2016. Profil Kesehatan Republik Indonesia Tahun 2016. Diakses pada tanggal 12 januari 2019. Pukul 19.20 Wib.

Nyoman Supariasa Dewa I, 2016. Penilaian Status Gizi. Ed. 2. Jakarta: EGC.

Notoatmodjo. 2012. Metodelogi penelitian kesehatan. Jakarta. Rineke cipta.

Nursalam. 2011. Konsep Dan Penerapan Metodelogi Penelitian Ilmu Keperawatan. Jakarta: Salemba Medika.

Noky Tri Rachmadianto. 2014. Evektifitas pemberian tablet tambah darah terhadap kadar hb siswi SLTPN 1 Donorojo Kecamatan Donorojo Kabupaten Pacitan. Surakarta: Universitas Muhammadiyah Surakarta.

Riwidikdo Handoko. 2010. Statistik Untuk Penelitian Kesehatan Dengan Aplikasi Program $R$ Dan SPSS. Yogyakarta: Pustaka Rihama.

Rohmani Afiana. 2013. Hubungan Status Gizi Dengan Anemia Pada Remaja Putri Disekolah Menengah Pertama Muhammadiyah 3 Semarang. Jurnal Kedokteran Muhammadiyah, Vol 1. 
Salma Aidallal. 2016. Iron Deficiency Anaemia. Journal International Of Cancer Research And ImmuneOncology, Volume 2, Issue 1

Saridewi Wisdyana. 2017. The Analysis of Different Average of Hemoglobin Increase between Adolescent Girls who Regularly and Irregularly Consume Iron Tablets at Patriot Bangsa Junior High. International Seminar on Global Health (ISGH) $2017 \quad$ Jenderal Achmad Yani Cimahi School of Health Sciences.

Sugiyono. 2017. Statistika Untuk Penelitian. Bandung : Alfabeta

Sugiyono. 2013. Metodologi Penelitian Kuantitatif, Kualitatif Dan $R \quad \& \quad D$. bandung: Alfabeta.

Tesfaye Melkam, Dkk. 2015. Anemia And Iron Deficiency Among School Adolescents Burden Severity And Determinant Factors In Southwest Ethiopia. Adolescent Health, Medicine And Therapeutics: Devopress.
Cahyaningtyas kartika dwi. 2017. Pengaruh Konsumsi Tablet Fe Terhadap Peningkatan Kadar Hemoglobin Pada Remaja Putri Di Sman 2 Ngaglik Kabupaten Sleman. Yogyakarta: Universitas Aisyiyah.

Kristyan nanik 2011. Perbedaan Kadar Hemoglobin Sebelum Dan Setelah Pemberian Tablet Besi ( Fe ) Pada Santri Putri Di Pondok Pesantren Al-Hidayah Kabupaten Grobogan. Semarang: Universitas Negeri Semarang

Kemenkes RI. 2014. Peraturan Mentri Kesehatan Republik Indonesia Nomer 88. Tentang standar tambah darah bagi wanita subur dan ibu hamil. Jakarta: Menteri Kesehatan Republik Indonesia.

Hedi R. Dewoto, S. Wardhini B.P . 2013. Farmakologi Dan Terapi. Ed. 5. Departemen Farmakologi Dan Terapeutik Fakultas Kedokteran Universitas Indonesia. Jakarta: Balai Penerbit FKUI Jakarta. 